\title{
Colonic single-stripe sign
}

\author{
Orapin Tanapanpanit, ${ }^{1}$ Krit Pongpirul $^{2}$
}

${ }^{1}$ Digestive Disease Center, Bumrungrad International Hospital, Bangkok, Thailand ${ }^{2}$ Faculty of Medicine, Department of Preventive and Social Medicine, Chulalongkorn University, Bangkok, Thailand

\section{Correspondence to} Dr Krit Pongpirul, doctorkrit@gmail.com

Accepted 5 September 2015

\section{DESCRIPTION}

An 81-year-old woman presented with sudden abdominal cramp-like pain with bloody diarrhoea for $4 \mathrm{~h}$ before admission. She had suffered three

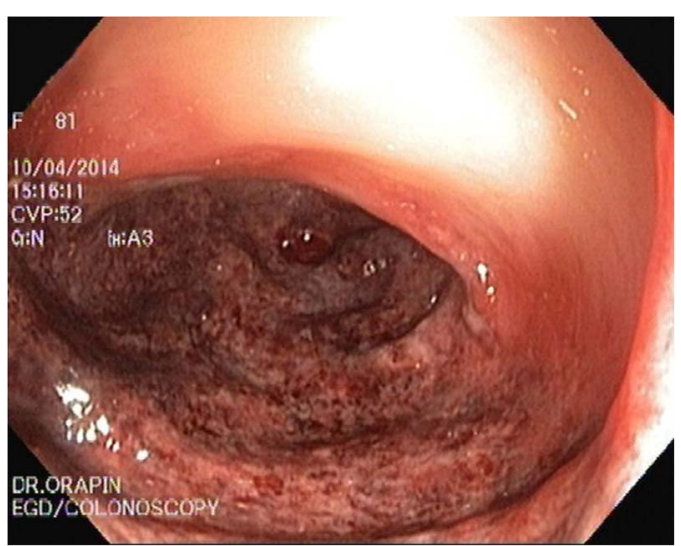

Figure 1 Colonic single-stripe sign. episodes of watery diarrhoea, followed by bright red stools after finishing dinner. Vital signs and cardiopulmonary conditions were within normal limits, with no orthostatic hypotension. Mild tenderness over the right lower quadrant was noted. Initial laboratory findings were normal except for serum creatinine level, which was $1.56 \mathrm{mg} / \mathrm{dL}$. The patient had no history of radiation exposure. Colonoscopy was performed within $6 \mathrm{~h}$ after her arrival because of the active bleeding. The study revealed 'colonic single-strip sign'-a linear ulcer running longitudinally, commonly found along the antimesenteric colonic wall at the sigmoid colonsuggestive of ischaemic colitis (figure 1). ${ }^{12}$ The histological finding of ischaemic colitis is focal crypt dropout in the early stage (figure 2). Advanced ischaemia shows epithelial loss, presence of acute and chronic inflammatory cells, and submucosal congestion (figure 3 ). To confirm diagnosis, careful biopsy was performed before terminating the session, to prevent complication. CT performed

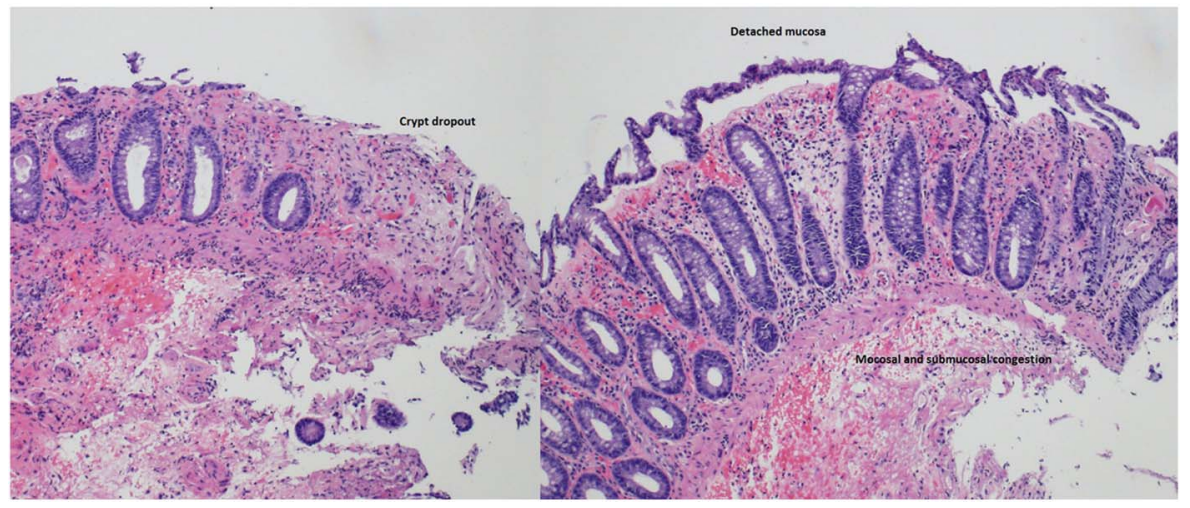

Figure 2 Detached mucosa and focal crypt dropout in early stage.

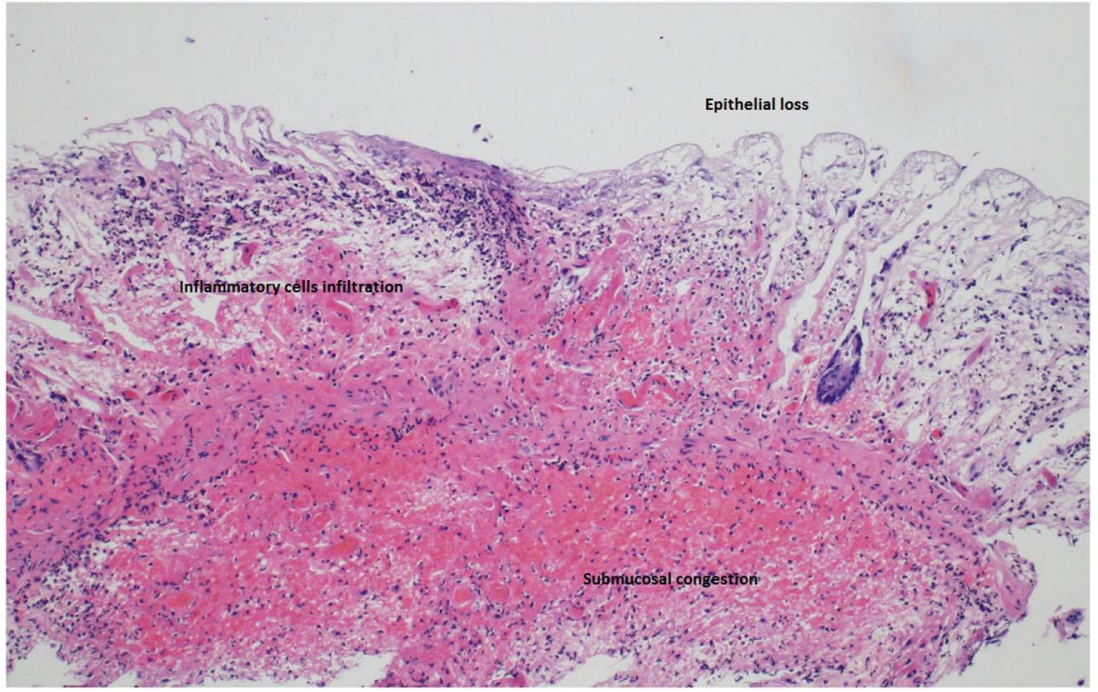

Figure 3 Epithelial loss, acute and chronic inflammatory cells, and submucosal congestion. 


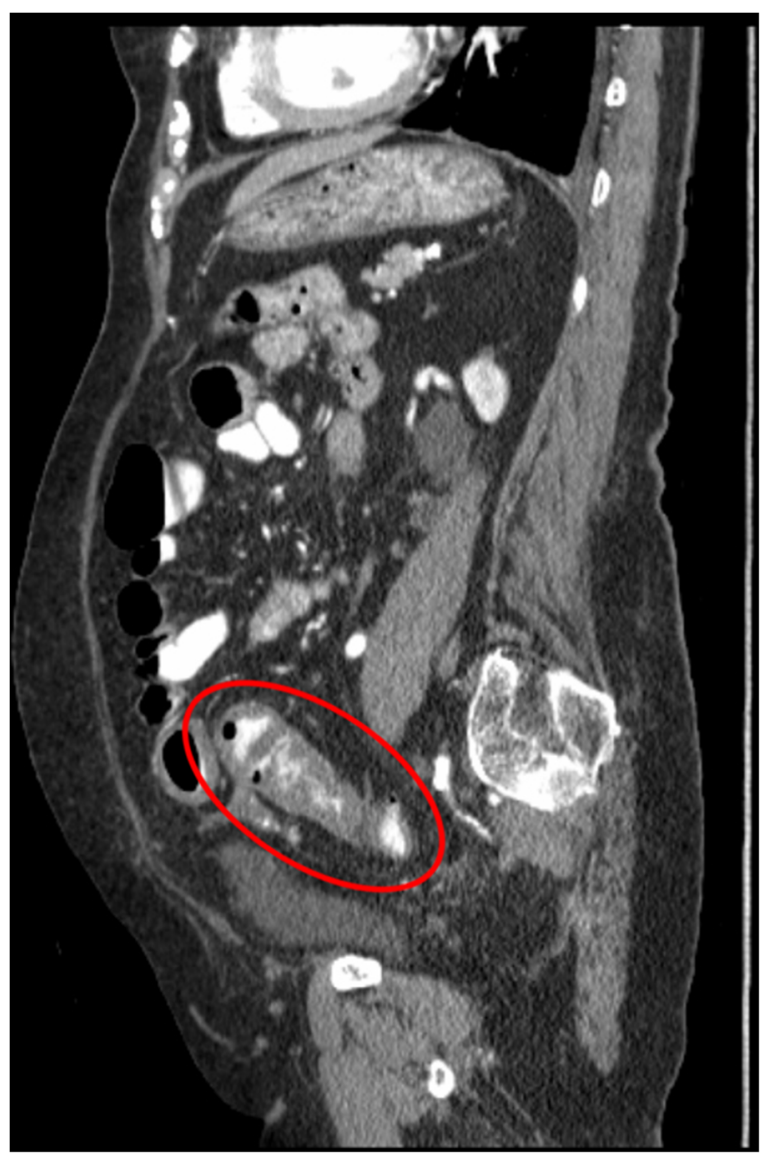

Figure 4 Bowel wall thickening, thumb printing and pericolonic stranding (lateral).

\section{Learning points}

- A colonic single-stripe sign is the typical colonoscopic finding of ischaemic colitis.

- Ischaemic colitis can be managed using a non-operative approach.

- Biopsy should be carefully performed to confirm the diagnosis.

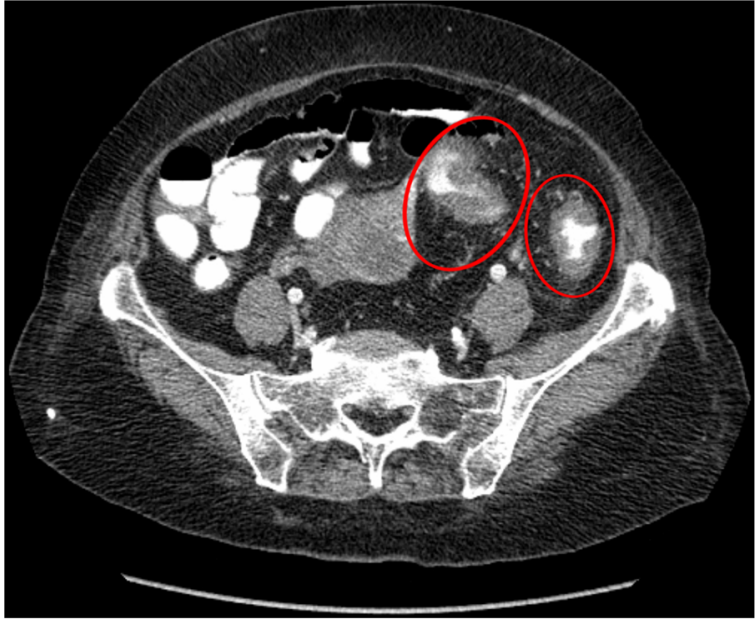

Figure 5 Bowel wall thickening, thumb printing and pericolonic stranding (axial).

later revealed bowel wall thickening, thumb printing and pericolonic stranding of the area supplied by the inferior mesenteric artery (figures 4 and 5). Potential infectious causes were ruled out based on negative findings for Clostridium difficile toxins A and B in stool, as well as negative stool, urine and blood culture. A non-operative approach was used, with successful reversion to a more normal colon.

Acknowledgements The authors would like to thank Dr Samornmas Kanngurn for the pathological findings.

Contributors OT was the primary physician, made the diagnosis, managed the case and prepared the first draft of the manuscript. KP contributed to the concept, and helped to draft and revise the manuscript.

Competing interests None declared.

Patient consent Obtained.

Provenance and peer review Not commissioned; externally peer reviewed.

\section{REFERENCES}

1 Green BT, Tendler DA. Ischemic colitis: a clinical review. South Med J 2005;98:217-22.

2 Zuckerman GR, Prakash C, Merriman RB, et al. The colon single-stripe sign and its relationship to ischemic colitis. Am J Gastroenterol 2003;98:2018-22.

3 Elder K, Lashner BA, Al Solaiman F. Clinical approach to colonic ischemia. Cleve Clin J Med 2009;76:401-9.

Copyright 2015 BMJ Publishing Group. All rights reserved. For permission to reuse any of this content visit http://group.bmj.com/group/rights-licensing/permissions.

BMJ Case Report Fellows may re-use this article for personal use and teaching without any further permission.

Become a Fellow of BMJ Case Reports today and you can:

- Submit as many cases as you like

- Enjoy fast sympathetic peer review and rapid publication of accepted articles

- Access all the published articles

- Re-use any of the published material for personal use and teaching without further permission

For information on Institutional Fellowships contact consortiasales@bmjgroup.com

Visit casereports.bmj.com for more articles like this and to become a Fellow 